\title{
Serum Protein Profile of Juvenile Pacu (Piaractus mesopotamicus) and Dourado (Salminus brasiliensis) Fed Bovine Colostrum as Partial Source of Protein in the Diet
}

\author{
Debora Moretti $^{1 *}$ (1), Wiolene Nordi ${ }^{2}$ (i), Raul Machado-Neto' ${ }^{1}$ \\ University of São Paulo, Luiz de Queiroz College of Agriculture, Department of Animal Science, Piracicaba, Brazil \\ ${ }^{2}$ Agriculture and Agri-Food Canada, Lethbridge Research and Development Centre, Government of Canada, Alberta, Canada
}

ORCID IDs of the authors: D.M. 0000-0003-0912-9989; W.N. 0000-0003-3666-6245; R.M.N. 0000-0002-5982-2776.

Please cite this article as: Moretti D, Nordi W, Machado-Neto R. Serum Protein Profile of Juvenile Pacu (Piaractus mesopotamicus) and Dourado (Salminus brasiliensis) Fed Bovine Colostrum as Partial Source of Protein in the Diet. Eur J Biol 2018; 77(2): 59-64.

\begin{abstract}
Objective: The electrophoretic profile of serum proteins was investigated in juvenile Piaractus mesopotamicus and Salminus brasiliensis fed with diets containing bovine colostrum, a nutraceutical food, in lyophilized form (LBC) for either 30 or 60 days.

Materials and Methods: Blood samples were collected from juveniles of $P$. mesopotamicus and S. brasiliensis fed for either 30 or 60 days with diets containing $0 \%, 10 \%$ or $20 \%$ of LBC. Serum protein fractions were then determined by electrophoresis in agarose gel. Results: The P. mesopotamicus, an omnivorous fish, showed six serum protein fractions, while the S. brasiliensis, a carnivorous fish, showed four serum protein fractions. In both species the albumin fraction showed higher protein content at 30 days than at 60 days $(p<0.05)$, indicating an inverse relationship with growth. The $5^{\text {th }}$ and $4^{\text {th }}$ fraction in mobility from the P. mesopotamicus and $S$. brasiliensis serum, respectively, were positioned in a gamma-globulin zone. In P. mesopotamicus, the concentration of protein in the gamma-globulin zone was higher at 60 days than at 30 days $(p<0.05)$. In S. brasiliensis, in turn, the concentration of protein in the gamma-globulin zone was higher at 30 days than at 60 days $(p<0.05)$. In juvenile $P$. mesopotamicus, a higher concentration of protein was also observed in the gamma-globulin zone in the $0 \% \mathrm{LBC}$ compared to $10 \%$ and $20 \% \mathrm{LBC}(\mathrm{p}<0.05)$. Thus, the feeding period influenced only the fractions that were positioned in the albumin and gamma-globulin migration zone in both species.

Conclusion: The consumption of bovine colostrum decreased the concentration of protein in gamma-globulin fraction of the $P$. mesopotamicus, indicating that these juveniles had either less stimulus for their own synthesis of defense elements or an immunosuppressive effect of bovine colostrum ingestion.
\end{abstract}

Keywords: Colostrum, teleost, omnivorous, carnivorous, electrophoresis

\section{INTRODUCTION}

Fish farming has increased mainly due to a greater demand for healthier meats for human consumption (1). However, the intensive production of these species presents a great challenge for the producer as a concentration of large populations increases the predisposition to bacterial and parasitic diseases (2). This problem is especially critical in the early stages of life of teleosts (3). Therefore, the formulation of diets that contribute to the health and well-being of juveniles are of great relevance.
Bovine colostrum is the first mammal lacteal secretion that is crucial for nutritional, metabolic and endocrine status of neonates $(4,5)$. The effects of colostrum consumption include the protection of the enteric and respiratory tract and reduction in mortality and morbidity of the newborn (6-8). The high nutritional value and concentration of biological molecules, such as antioxidant and antimicrobial factors, designate colostrum as a nutraceutical food (9). This lacteal secretion from bovine has been widely used as an immunological and nutritional source for sev-

This study was presented at the $39^{\text {th }}$ CONBRAVET-Congresso Brasileiro de Medicina Veterinária, December $4^{\text {th }}-6^{\text {th }}, 2012$, São Paulo, Brazil. 
eral species, including swine and rodents $(10,11)$. In fish, the supply of lyophilized bovine colostrum is an innovative conception and the effects of this food on fish health has been explored by different approaches (12-14).

In Brazil, Piaractus mesopotamicus and Salminus brasiliensis, popularly known as pacu and dourado, are neotropical species with favorable features for commercial production. Besides be-

Table 1. Chemical composition of experimental pelleted diets fed to juvenile Piaractus mesopotamicus

\begin{tabular}{|c|c|c|c|}
\hline \multirow[b]{2}{*}{ Ingredient (g kg $\left.{ }^{-1}\right)$} & \multicolumn{3}{|c|}{ Diets $^{1}$} \\
\hline & $0 \%$ & $10 \%$ & $20 \%$ \\
\hline Bovine colostrum $\left(679 \mathrm{~g} \mathrm{~kg}^{-1} \mathrm{CP}\right)$ & - & 100 & 200 \\
\hline Soybean meal (45 $\left.\mathrm{g} \mathrm{kg}^{-1} \mathrm{CP}\right)$ & 265 & 76.7 & - \\
\hline Wheat meal & 238 & 311.8 & 311.8 \\
\hline Poultry by-product meal & 200 & 200 & 131 \\
\hline Broken rice & 188 & 198 & 200 \\
\hline Fish meal (55\% CP) & 50 & 50 & 50 \\
\hline Fish oil & 46.2 & 40 & 45.7 \\
\hline DL-methionine & 2.4 & 3.4 & 4.7 \\
\hline L-lysine $\mathrm{HCl}$ & - & 6 & 11.5 \\
\hline BHT & 2 & 2 & 2 \\
\hline Cellulose & - & 3.4 & - \\
\hline Calcareous & - & - & 14.7 \\
\hline Corn grain & - & - & 9.3 \\
\hline Premix ${ }^{2}$ & 10 & 10 & 10.5 \\
\hline \multicolumn{4}{|l|}{ Chemical composition $\left(\mathrm{g} \mathrm{kg}^{-1}\right)^{3}$} \\
\hline Dry matter & 940.6 & 933.4 & 936.4 \\
\hline Crude protein & 324.6 & 314.9 & 322 \\
\hline Crude fiber & 30 & 27.7 & 30.7 \\
\hline Fat & 90.5 & 98.2 & 109.3 \\
\hline Ash & 106.4 & 101.1 & 92.8 \\
\hline Gross energy (MJ kg ${ }^{-1}$ ) & 18 & 18.2 & 18.3 \\
\hline
\end{tabular}

${ }^{1} 0 \%$ - diets containing $0 \%$ of lyophilized bovine colostrum; $10 \%$ - diets containing $10 \%$ of lyophilized bovine colostrum; $20 \%$ - diets containing $20 \%$ of lyophilized bovine colostrum.

${ }^{2}$ Guabi Nutrição Animal, Campinas, São Paulo (ingredient per kg). Vitamins: A, 2,500 Ul; D3, 600.000 UI; E, 37.500 Ul; K3, 3,750 mg; C, 50,000 mg; B1, 4.000 mg; $B 2,4,000$ mg; $B 6,4,000$ mg; $B 12,4,000$ mg; calcium pantothenate, 12,000 $\mathrm{mg}$; biotin, $15 \mathrm{mg}$; acid folic, 1,250 mg; niacin, 22,500 mg. Mineral: $\mathrm{Cu}, 2,500$ mg; Zn, 12,500 mg; l, 375 mg; Se, 87.5 mg; Co, 125 mg; Mn, 12,500 mg; Fe, $15,000 \mathrm{mg} ; \mathrm{BHT}, 15,000 \mathrm{mg}$.

${ }^{3}$ Original matter basis. ing a species of interest for the sport of fishing, Piaractus mesopotamicus and Salminus brasiliensis present good performance and acceptance by the consumers $(2,15,16)$. However, information about their physiology and the effects of nutraceutical foods on their health is still being gathered. The electrophoresis of proteins from blood plasma or serum can be used in humans and animals to provide information on acute and chronic inflammatory processes and consequently health $(17,18)$. In recent decades, the study of blood protein fractions from different species has increased, including works involving fish, which focus on the relation between water pollution and fish health (19-22). The effects of diet on protein profile, especially gamma globulin fraction where antibodies are positioned, are of great relevance to evaluate the health and immunity of fish.

Since electrophoresis has been proposed to aid in the diagnosis of disease, normal reference ranges for serum protein levels still need to be established in different species of fish. Considering colostrum as a nutraceutical food, there is the possibility of this food modulating immunity, and consequently, fish health. Thus, this study investigates the electrophoretic prolife of serum proteins of juvenile Piaractus mesopotamicus and Salminus brasilienesis fed diets with bovine colostrum, a nutraceutical food, in the lyophilized form (LBC).

\section{MATERIAL AND METHODS}

\section{Diets}

The first lacteal secretion from multiparous Holstein cows was frozen at $-20^{\circ} \mathrm{C}$ and, thereafter, lyophilized. This powder was homogenized to obtain a homogeneous sample, which was analyzed for the bromatological composition. Considering the nutritional composition of bovine colostrum, isonitrogenous and isoenergetic pelleted diets were formulated to attend to the requirements of juveniles Piaractus mesopotamicus and Salminus brasiliensis (Tables 1 and 2). After the homogenization of the ingredients, the diets were pelletized, dried (at a temperature of approximately $46^{\circ} \mathrm{C}$ ) and stored in a dry place until the time of supply. Chemical compositions of experimental pelleted diets were subsequently submitted to chemical analysis (23).

\section{Experiment}

Juvenile Piaractus mesopotamicus and Salminus brasiliensis (8.5 \pm 0.7 and $13.3 \pm 0.9 \mathrm{~g} ; 7.8 \pm 0.3$ and $10.8 \pm 0.3 \mathrm{~cm}$, respectively) were randomly distributed in 36 tanks ( 324 pacu in 18 tanks and 270 dourado in 18 tanks) with controlled water quality parameters $\left(26.8 \pm 1.5^{\circ} \mathrm{C}, 5.8 \pm 1.0 \mathrm{mg} \mathrm{L}^{-1}\right.$ of dissolved oxygen and $<0.05$ $\mathrm{mg} \mathrm{L}^{-1}$ dissolved ammonia). After adaptation for 10 and seven days, respectively, diets containing $0 \%, 10 \%$ or $20 \%$ bovine colostrum in LBC were hand-fed to apparent satiety twice a day (08h30 and 16h30) for either 30 or 60 days (authorized by the ESALQ/USP ethics committee).

Seven fish were sampled on the $30^{\text {th }}$ and $60^{\text {th }}$ experimental day after $24 \mathrm{~h}$ fasting and anesthesia with benzocaine $\left(0.1 \mathrm{~g} \mathrm{~L}^{-1}\right)$. Blood samples obtained from the caudal vein were centrifuged and the serum was stored at $-20^{\circ} \mathrm{C}$. 


\section{Analyses}

The total serum protein was determined (24) and an electrophoretic analysis was performed in an agarose gel (CELMGEL) for $30 \mathrm{~min}$ at 90 volts. After staining with $0.2 \%$ starch black for 5 min., a reading of the protein fractions in a densitometer (CELM DS35) with a wavelength of $520 \mathrm{~nm}$ was performed. The software CELM SE-250 was used to calculate the relative percentage of each protein fraction from the area under the curve created by the protein fraction. No attempt has been made to identify protein components of the sera studied as albumin or globulin. The electrophoretic fractions were numbered according to the increasing mobility.

\section{Statistical Analysis}

Serum variables were analyzed based on a $2 \times 3$ completely randomized factorial design using SAS software (SAS Institute Inc., 2004), taking into consideration the three diets and two feeding periods (30 and 60 experimental days). An analysis of variance was per-

Table 2. Chemical composition of experimental pelleted diets fed to juvenile Salminus brasiliensis

\begin{tabular}{|c|c|c|c|}
\hline \multirow[b]{2}{*}{ Ingredient (g kg-1) } & \multicolumn{3}{|c|}{ Diets $^{1}$} \\
\hline & $0 \%$ & $10 \%$ & $20 \%$ \\
\hline Bovine colostrum (679 $\left.\mathrm{g} \mathrm{kg}^{-1} \mathrm{CP}\right)$ & - & 100 & 200 \\
\hline Soybean meal (45 $\left.\mathrm{g} \mathrm{kg}^{-1} \mathrm{CP}\right)$ & 230 & 230 & 230 \\
\hline Poultry by-product meal & 204.8 & 119.8 & 24.5 \\
\hline Fish meal (55 $\left.\mathrm{g} \mathrm{kg}^{-1} \mathrm{CP}\right)$ & 320 & 300 & 300 \\
\hline Fish oil & 95 & 90 & 85.2 \\
\hline Premix ${ }^{2}$ & 10 & 10 & 10 \\
\hline BHT & 0.2 & 0.2 & 0.2 \\
\hline Cellulose & 20 & 30 & 30 \\
\hline Corn (whole grain) & 120 & 120 & 120 \\
\hline \multicolumn{4}{|l|}{ Chemical composition $\left(\mathrm{g} \mathrm{kg}^{-1}\right)^{3}$} \\
\hline Dry matter & 924.4 & 936.7 & 925.7 \\
\hline Crude protein & 422 & 425.1 & 444.7 \\
\hline Crude fiber & 18.9 & 29.2 & 37.3 \\
\hline Fat & 140.7 & 140.6 & 133.7 \\
\hline Ash & 121.9 & 114.5 & 91.1 \\
\hline Gross energy (MJ kg ${ }^{-1}$ ) & 20.8 & 21.1 & 20.8 \\
\hline \multicolumn{4}{|c|}{ 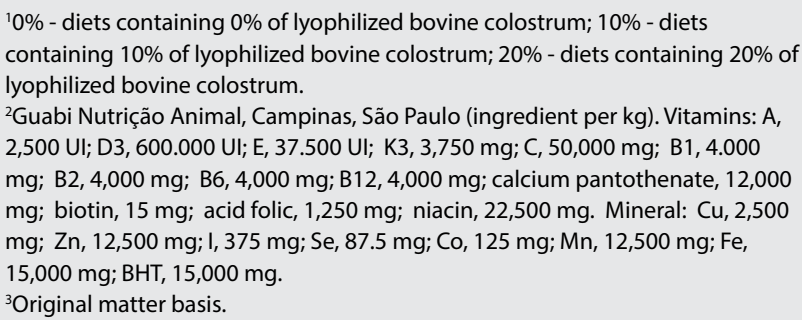 } \\
\hline
\end{tabular}

formed using the general linear model and comparisons between pairs of means were made using the Tukey test considering $\mathrm{p}<0.05$.

\section{RESULTS}

\section{Electrophoretic profile of serum proteins of juvenile pacu (Piaractus mesopotamicus)}

Using the software SDS-60 (Celm), six fractions in the serum of juvenile Piaractus mesopotamicus were identified (Figures 1 and 2). These fractions were quantified by the software considering the value of serum total protein (Table 3 ). The effect of the period was observed for the $2^{\text {nd }}$ fraction $(p<0.05)$, with a higher value at 30 days compared to 60 days. The $6^{\text {th }}$ fraction was affected by the diet and period $(p<0.05)$, with higher values at 60 days and in the group $0 \% \mathrm{LBC}$.

\section{Electrophoretic profile of serum proteins of juvenile doura- do (Salminus brasiliensis)}

Using the software SDS-60 (Celm), four fractions in the serum of juvenile Salminus brasiliensis were identified (Figures 3 and 4). These fractions were quantified by the software considering the

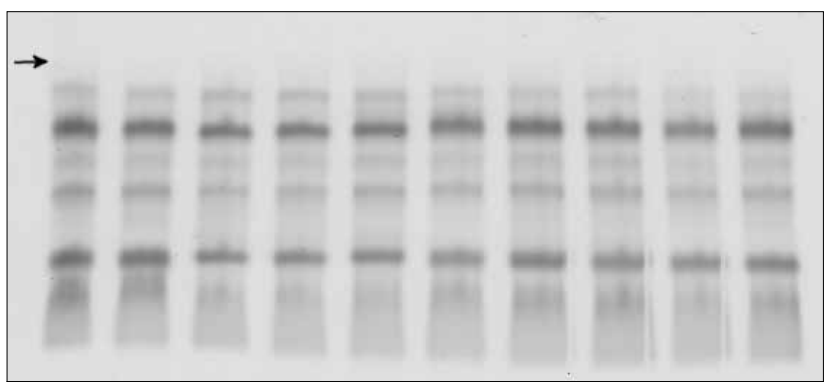

Figure 1. Electrophoretic analyzes of 10 serum samples of juvenile pacu, Piaractus mesopotamicus. Arrow: start of the race

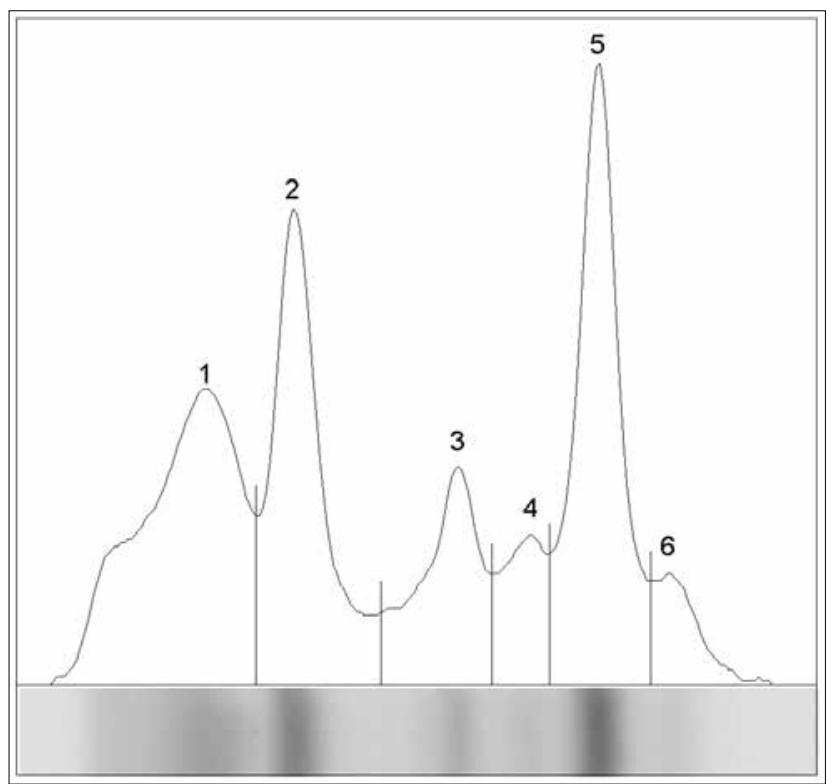

Figure 2. Electrophoretic profile of serum proteins of juvenile pacu, Piaractus mesopotamicus, revealing six fractions (in order from fastest to slowest) 
Table 3. Serum protein fractions (in order from fastest to slowest) and total protein ( $\mathrm{g} \mathrm{dL}^{-1}$ ) in juvenile Piaractus mesopotamicus (mean \pm standard error) fed lyophilized bovine colostrum

\begin{tabular}{|c|c|c|c|c|c|c|c|c|}
\hline & \multicolumn{3}{|c|}{ Diet $^{1}$} & \multicolumn{2}{|c|}{ Feeding period (days) } & \multicolumn{3}{|c|}{ Effect $^{2}$} \\
\hline & $0 \%$ LBC & $10 \%$ LBC & $20 \%$ LBC & 30 & 60 & D & $\mathbf{P}$ & DXP \\
\hline Total protein & $4.00 \pm 0.23$ & $4.14 \pm 0.16$ & $3.95 \pm 0.11$ & $4.04 \pm 0.14$ & $4.03 \pm 0.12$ & NS & NS & NS \\
\hline Band 1 & $1.07 \pm 0.09$ & $1.18 \pm 0.06$ & $1.11 \pm 0.02$ & $1.09 \pm 0.05$ & $1.16 \pm 0.03$ & NS & NS & NS \\
\hline Band 2 & $0.80 \pm 0.04$ & $0.79 \pm 0.05$ & $0.76 \pm 0.06$ & $0.86 \pm 0.03$ & $0.69 \pm 0.03$ & NS & * & NS \\
\hline Band 3 & $0.54 \pm 0.03$ & $0.56 \pm 0.02$ & $0.54 \pm 0.02$ & $0.53 \pm 0.02$ & $0.56 \pm 0.01$ & NS & NS & NS \\
\hline Band 4 & $0.29 \pm 0.02$ & $0.32 \pm 0.01$ & $0.29 \pm 0.01$ & $0.29 \pm 0.01$ & $0.32 \pm 0.01$ & NS & NS & NS \\
\hline Band 5 & $0.97 \pm 0.05$ & $1.00 \pm 0.04$ & $1.00 \pm 0.05$ & $1.02 \pm 0.04$ & $0.97 \pm 0.03$ & NS & NS & NS \\
\hline Band 6 & $0.32 \pm 0.03^{a}$ & $0.27 \pm 0.01^{b}$ & $0.25 \pm 0.02^{b}$ & $0.24 \pm 0.01$ & $0.31 \pm 0.02$ & * & * & NS \\
\hline
\end{tabular}

${ }^{*} p<0.05$; NS- $p>0.05$; means followed by the same letter $(a, b)$ differ $(p<0.05) ; 10 \%$ LBC-juveniles fed $0 \%$ of lyophilized bovine colostrum; LBC $10 \%$-juveniles fed $10 \%$ of lyophilized bovine colostrum; $20 \%$ CBL-juveniles fed $20 \%$ of lyophilized bovine colostrum; 2D-diet effect, P-period effect; DxP-interaction between diet and period.

Table 4. Serum protein fractions (in order from fastest to slowest) and total protein ( $\mathrm{g} \mathrm{dL}-1$ ) in juvenile Salminus brasiliensis (mean \pm standard error) fed lyophilized bovine colostrum

\begin{tabular}{|c|c|c|c|c|c|c|c|c|}
\hline & \multicolumn{3}{|c|}{ Diet $^{1}$} & \multicolumn{2}{|c|}{ Feeding period (days) } & \multicolumn{3}{|c|}{ Effect $^{2}$} \\
\hline & $0 \%$ LBC & $10 \%$ LBC & $20 \%$ LBC & 30 & 60 & D & $\mathbf{P}$ & DXP \\
\hline Total protein & $3.37 \pm 0.08$ & $3.42 \pm 0.07$ & $3.38 \pm 0.12$ & $3.46 \pm 0.05$ & $3.33 \pm 0.08$ & NS & NS & NS \\
\hline Band 1 & $1.01 \pm 0.03$ & $1.13 \pm 0.04$ & $1.11 \pm 0.07$ & $1.16 \pm 0.03$ & $1.01 \pm 0.03$ & NS & $*$ & NS \\
\hline Band 2 & $1.45 \pm 0.05$ & $1.37 \pm 0.06$ & $1.37 \pm 0.05$ & $1.35 \pm 0.04$ & $1.44 \pm 0.04$ & NS & NS & NS \\
\hline Band 3 & $0.12 \pm 0.01$ & $0.13 \pm 0.01$ & $0.13 \pm 0.01$ & $0.13 \pm 0.01$ & $0.13 \pm 0.01$ & NS & NS & NS \\
\hline Band 4 & $0.79 \pm 0.03$ & $0.79 \pm 0.01$ & $0.76 \pm 0.03$ & $0.81 \pm 0.02$ & $0.75 \pm 0.01$ & NS & * & NS \\
\hline
\end{tabular}

${ }^{*} p<0.05$; NS-p $>0.05 ; 10 \%$ LBC-juveniles fed $0 \%$ of lyophilized bovine colostrum; LBC $10 \%$-juveniles fed $10 \%$ of lyophilized bovine colostrum; $20 \%$ CBL-juveniles fed $20 \%$ of lyophilized bovine colostrum; 2D-diet effect, P-period effect; DxP-interaction between diet and period.

value of serum total protein (Table 4). The effect of the period was observed for the $1^{\text {st }}$ and $4^{\text {th }}$ fractions $(p<0.05)$, with higher values at 30 days compared to 60 days.

\section{DISCUSSION}

The serum protein profile of juvenile pacu, Piaractus mesopotamicus, showed six fractions. Approximately $28 \%, 19 \%$, $14 \%, 8 \%, 25 \%$, and $7 \%$ of proteins were observed in the $1^{\text {st }}, 2^{\text {nd }}$, $3^{\text {rd }}, 4^{\text {th }}, 5^{\text {th }}$ and $6^{\text {th }}$ fraction, respectively. In the juvenile dourado, Salminus brasiliensis, four fractions were identified. The $1^{\text {st }}$ to $4^{\text {th }}$ fraction corresponded approximately to $32 \%, 41 \%, 5 \%$ and $22 \%$ of the serum total protein (25). Work with four species of Tilapia, seven serum fractions were observed in the T. nilotica, T. galilaea and T. aurea, while de T. zillii showed six serum fractions. The authors also observed differences in the protein concentration in each band and suggest that these results might be related to diet.

The $2^{\text {nd }}$ fraction in the serum of pacu and the $1^{\text {st }}$ fraction in the serum of dourado, Salminus brasiliensis, showed a higher protein concentration at 30 days compared to 60 days, indicating an inverse relationship with growth. As an additional investigation, bovine serum albumin (BSA, Sigma-Aldrich Co) was added to fish serum and samples were submitted again to electrophoresis analyses. The electrophoretic profile was not changed in both species; however, the $2^{\text {nd }}$ fraction from Piaractus mesopotamicus serum and the $1^{\text {st }}$ fraction from dourado serum showed a significant increase in its participation of total protein from 19\% to $43 \%$ and $36 \%$ to $53 \%$, respectively. These results indicated that these fractions are in the albumin migration zone and are probably the corresponding protein in fish. Thus, in juvenile pacu, the calculation of globulin by the difference of serum total protein and albumin is not adequate, since near $28 \%$ of serum proteins are in the $1^{\text {st }}$ fraction, which corresponds to pre-albumin proteins and are not considered in this calculation.

According to Atamanalp et al. (26) and Maceda Veiga et al. (27), environmental changes can affect the physiological and biochemical characteristics of fish blood, and the hematological and serum protein profiles are important indices in monitoring the effects 


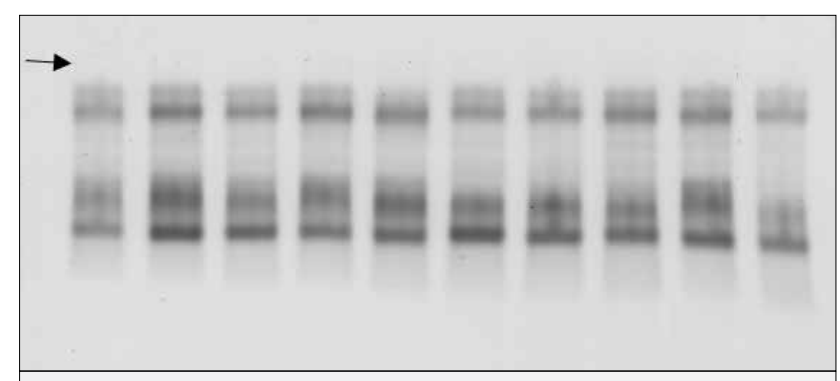

Figure 3. Electrophoretic analyzes of 10 serum samples of juvenile dourado, Salminus brasiliensis. Arrow: start of the race

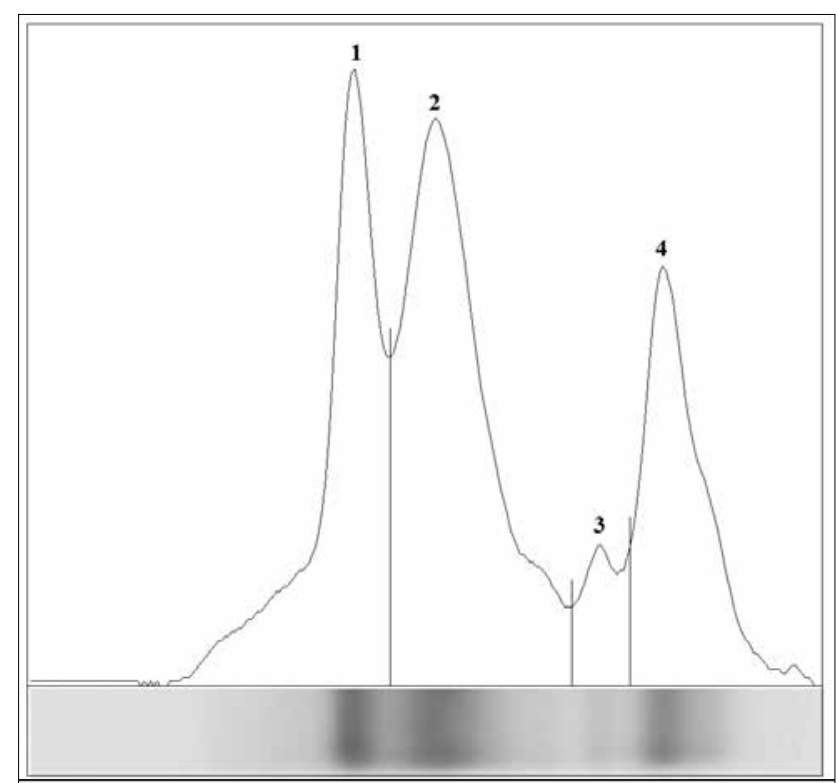

Figure 4. Electrophoretic profile of serum proteins of juvenile dourado, Salminus brasiliensis, revealing four fractions (in order from fastest to slowest)

of aquatic habitat changes suggests that the reduction of serum protein concentration is related to an adverse environment. The authors observed lower serum protein concentration in the Mugil cephalus exposed to different pHs. In the present work, Piaractus mesopotamicus and Salminus brasiliensis showed a reduction of protein concentration in the $2^{\text {nd }}$ and $1^{\text {st }}$ fractions, respectively, after 60 experimental days, suggesting a less favorable condition for fish. According to Fazio et al. (22), the reduction of protein concentration is due to protein catabolism, i.e. the process of converting blood and structural proteins to energy to produce higher energy, resulting in fish adaptation to a wide range of environmental conditions.

The $3^{\text {rd }}$ and $4^{\text {th }}$ fractions from Piaractus mesopotamicus serum and the $2^{\text {nd }}$ and $3^{\text {rd }}$ fractions from Salminus brasiliensis serum were positioned in an alpha-beta-globulin zone. Further studies should be conducted to better characterize each serum protein fraction since this information can be useful to fish health.

The $5^{\text {th }}$ and $6^{\text {th }}$ fraction from pacu serum and the $4^{\text {th }}$ fraction from dourado, Salminus brasiliensis, serum were positioned in a gamma-globulin zone, where immunoglobulin are usually expected. In this study, the concentration of this protein fraction in pacu,
Piaractus mesopotamicus, serum was higher at 60 days compared to 30 days while in dourado serum it was lower at 60 days compared to 30 days. According to Scapigliati et al. (28), the immunoglobulin levels increase consistently with age and size; however, other events like water oxygenation and season can also affect concentrations of this protein in serum. The authors observed that the hyperoxygenation of seawater resulted in a two-fold increase of immunoglobulins, from $3.9 \mathrm{mg} \mathrm{mL}^{-1}$ in running seawater, to 7.1 $\mathrm{mg} \mathrm{mL}^{-1}$ at $12 \mathrm{ppm} \mathrm{O}_{2} \mathrm{~L}^{-1}$. In juvenile Piaractus mesopotamicus, great concentrations of proteins were also observed in the $5^{\text {th }}$ fraction in the group that was not fed lyophilized bovine colostrum, 0\% LBC. This result suggests that the first lacteal bovine secretion, rich in immune and antimicrobial elements such as immunoglobulins, lactoferrin, lactoperoxidase and lysozyme (29), may have contributed to the protection of the juvenile. Consequently, the juveniles had less stimulus for their own synthesis of defense elements, probably immunoglobulin $\mathrm{M}$. On the other hand, this result can indicate an immunosuppressive effect of colostrum. According to Mandalapu et al. (30) human colostrum contains a factor (colostrum inhibitory factor XX) that inhibits the induction of interleukin 2 in T lymphocyte cell lines. Aldridge et al. (31), in turn, observed that colostrum feeding reduces the number of immunoglobulin positive cells in the lymphoid tissues of newborn calves.

As found by other authors using SDS-PAGE, the presence, position and amount of protein in serum fractions can be affected by pollutants, water quality and phylogenetic distance $(20,32-$ 36). Gicking et al. (37) states that plasma protein electrophoresis may be useful as a health assessment tool for evaluating injured sea turtles. The authors determined reference intervals for plasma protein fractions of wild Atlantic loggerhead sea turtles, Caretta caretta. In the present study, the values of protein concentration could be useful as reference ranges for the health of juvenile Piaractus mesopotamicus and Salminus brasiliensis.

The two species studied, Piaractus mesopotamicus and Salminus brasiliensis, showed different electrophoretic profiles of serum proteins. The first species, an omnivorous fish, showed six fractions while the second, a carnivorous fish, showed four fractions. Fractions that were positioned in the albumin and gamma-globulin migration zone were affected by feeding period, 30 or 60 experimental days, in both species, pacu and dourado. Bovine colostrum influenced the serum protein profile of the juvenile Piaractus mesopotamicus with some indications of positive protective effects.

Ethics Committee Approval: Ethics committee approval was received for this study from the ethics committee of CEUA-ESALQ.

Peer-review: Externally peer-reviewed.

Author Contributions: Concept - R.M.N., D.M.; Design - R.M.N., D.M., W.N.; Supervision - R.M.N.; Resource - R.M.N., D.M.; Materials - R.M.N.; Data Collection and/or Processing - D.M., W.N.; Analysis and/or Interpretation - D.M.; Literature Search - D.M.; Writing - D.M.; Critical Reviews - R.M.N.

Conflict of Interest: The authors have no conflict of interest to declare.

Financial Disclosure: This study was supported by São Paulo Research Foundation (FAPESP), process 2012/50284-2 and 2011/51713-1 and National Council for Scientific and Technological Development (CNPq). 


\section{REFERENCES}

1. Queiroz JF, Lourenço JNP, Kitamura PC, Scorvo-Filho JD, Cyrino JEP, Castagnolli N, Valenti WC, Bernardino G. Aquaculture in Brazil: research priorities and potential for further international collaboration. World Aquac 2005; 36: 45-50.

2. Urbinati EC, Gonçalves FD. Pacu (Piaractus mesopotamicus). In: Baldisseroto B, Gomes LC, editors Espécies nativas para piscicultura no Brasil. Santa Maria, RGS, BR: UFSM; 2005. pp 225-46.

3. Swain P, Nayak SK. Role of maternally derived immunity in fish. Fish Shellfish Immunol 2009; 27(2): 89-99.

4. Blum JW, Hammon H. Colostrum effects on the gastrointestinal tract, and on nutritional, endocrine and metabolic parameters in neonatal calves. Liv Prod Sci 2000; 66: 151-9.

5. Blum JW, Baumrucker CR. Colostral and milk insulin-like growth factors and related substances: mammary gland and neonatal (intestinal and systemic) targets. Domest Anim Endocrinol 2002; 23(1-2): 101-10.

6. Daniele C, Machado-Neto R, Baracat RS, Bessi R. Effect of different feeding programs employing supplemental colostrum on serum total protein and albumin, and performance of newborn calves. Sci Agric 1994; 51(2): 381-8.

7. Nocek JE, Braund DG, Warner RG. Influence of neonatal colostrum administration, immunoglobulin, and continued feeding of colostrum on calf gain, health and serum protein. J Dairy Sci 1984; 67(2): 319-33.

8. Baracat RS, Neto RM, Daniele C, Bessi R, Packer IU. Extended colostrum feeding and passive immunity in newborn calves. Pesq Agrop Bras 1997; 32: 215-20.

9. Pandey NN, Dar AA, Mondal DB, Nagaraja L. Bovine colostrum: a veterinary nutraceutical. J Vet Med Anim Health 2011; 3: 31-5.

10. Huguet A, Sève B, Le Dividich J, Le Huërou-Luron I. Effects of a bovine colostrum-supplemented diet on some gut parameters in weaned piglets. Reprod Nutr Dev 2006; 46(2): 167-78.

11. Bodammer P, Maletzki C, Waitz G, Emmrich J. Prophylatic application of bovine colostrum ameliorates murine colitis via induction of immunoregulatory cells. J Nutr 2011; 141(6): 1056-61.

12. Rodrigues APO, Pauletti P, Kindlein L, Delgado EF, Cyrino JEP, Machado-Neto R. Intestinal histomorphology in Pseudoplatystoma fasciatum fed bovine colostrum as source of protein and bioactive peptides. Sci Agr 2010; 67(5): 524-30.

13. Cruz TMP, Moretti DB, Nordi WM, Cyrino JEP, Machado-Neto R. Dietary lyophilized colostrum alters distribution of goblet cells and the intestinal epithelium of Piaractus mesopotamicus. Aquaculture 2017; 468: 286-92.

14. Moretti DB, Nordi WM, Cruz TMP, Machado-Neto R. Catalase, superoxide dismutase, glutathione peroxidase and oxygen radical absorbance capacity in the gut of juvenile pacu Piaractus mesopotamicus and dourado Salminus brasiliensis fed bovine first milk secretion. Lat Am J Aquat Res 2017; 45(4): 717-23.

15. Venturieri RL. Pesque-pague no Estado de São Paulo: Vetor de desenvolvimento e opção de turismo e lazer. 1st ed. São Paulo, SP, BR: ECO Associação para Estudos do Ambiente; 2003.

16. Esteves $\mathrm{KE}$, Sant'anna $\mathrm{CL}$. Pesqueiros sob uma visão integrada de meio ambiente, Saúde Pública e Manejo: Um estudo da região metropolitana de São Paulo. São Carlos, SP, BR: Editora Rima; 2006.

17. Doherty NS, Littman BH, Reilly K, Swindell AC, Buss JM, Anderson $\mathrm{NL}$. Analysis of changes in acute-phase plasma proteins in an acute inflammatory response and in rheumatoid arthritis using two-dimensional gel electrophoresis. Electrophoresis 1998; 19(2): 355-63.

18. Cray C, Besselsen DG, Hart JL, Yoon D, Rodriguez M, Zaias J, Altman $\mathrm{NH}$. Quantitation of acute phase proteins and protein electrophoresis in monitoring the acute inflammatory process in experimentally and naturally infected mice. Comp Med 2010; 60(4): 263-71.

19. Kekic M, dos Remedios CG. Electrophoretic monitoring of pollutants: effect of cations and organic compounds on protein inter- actions monitored by native gel electrophoresis. Electrophoresis 1999; 20(10): 2053-8.

20. Sharaf-Eldeen Kh, Abdel-Hamid NA. Sublethal effects of copper sulphate, malathion and paraquat on protein pattern of Oreochromis niloticus. Egypt J Aquat Biol Fish 2002; 6(2): 167-82.

21. Osman AGM, Al-Awadhi RM, Harabawy ASA, Mahmoud UM. Evaluation of the use of protein electrophoresis of the African catfish Clarias gariepinus (Burchell, 1822) for biomonitoring aquatic pollution. Environ Res J 2010; 4(3): 235-43.

22. Fazio F, Marafioti S, Torre A, Sanfilippo M, Panzera M, Faggio C. Haematological and serum protein profiles of Mugil cephalus: effect of two different habitats. Ichthyol Res 2013; 60: 36-42.

23. Association of Official Analytical Chemists. Oficial methods of analyses. Washington, DC, USA: Association of Official Analytical Chemists; 1990.

24. Reinhold JG. Total protein, albumin and globulin. In: Reiner M, editor. Standard Methods of Clinical Chemistry. New York, NY, USA: Academic Press; 1953. pp. 88.

25. Badawi HK. Electrophoretic studies of serum proteins of four Tilapia species (Pisces). Mar Biol 1971; 8(2): 96-8.

26. Atamanalp M, Yanik T, Haliloglu HI, Sitki AM. Alterations in the haematological parameters of rainbow trout, Oncorhynchus mykiss, exposed to cypermethrin. Israeli J Aquaculture 2002; 54(3): 99-103.

27. Maceda-Veiga A, Monroya M, Viscorb G, De Sostoa A. Changes in non-specific biomarkers in the Mediterranean barbell (Barbus meridionalis) exposed to sewage effluents in a Mediterranean stream (Catalonia, NE Spain). Aquat Toxicol 2010; 100(3): 229-37.

28. Scapigliati G, Scalia D, Marras A, Meloni S, Mazzini M. Immunoglobulin levels in the teleost sea bass Dicentrarchus labrax (L.) in relation to age, season, and water oxygenation. Aquaculture 1999; 174(3-4): 207-12.

29. Boudry C, Thewis A. Bovine colostrum as a natural growth factor for newly-weaned piglets: a review. Bull UASVM Anim Sci Biotechnol 2009; 66: 1-2.

30. Mandalapu P, Pabst HP, Paetkau V. A Novel immunosuppressive factor in human colostrum. Cell Immunol 1995; 162(2): 178-84.

31. Aldridge BM, McGuirk SM, Lunn DP. Effect of colostral ingestion on immunoglobulin-positive cells in calves. Vet Immunol Immunopathol 1998; 62(1): 51-64.

32. Menezes MR, Qasim SZ. Use of electrophoresis and immunoelectrophoresis in taxonomic and pollution studies. Proc Indian Acad Sci (Anim Sci) 1984; 93(3): 179-98.

33. El-Serafy SS, Abdel-Hamide NAH, Awwad MH, Azab MS. Comparative study on electrophoretic protein pattern characterization of Tilapia species in the river nile, Egypt. Egypt J Aqual Biol \& Fish 2006; 10(2): 147-78.

34. Yilmaz M, Yilmaz HR, Alas A. An electrophoretic taxonomic study on sérum proteins of Acanthobrama marmid, Leuciscus cephalus, and Chondrostoma regium. Eurasia J Biosci 2007; 1(1): 22-7.

35. Shagufta SSJK, Gayasuddin M. Comparative study of serum proteins of man and four Teleosts: using polyacrylamide gel electrophoresis. Adv Biol Res 2011; 5(3): 170-3.

36. Akinwande AA, Fagbenro OA, Adebayo OT. Serum protein pattern in interspecific and intergeneric hybrids of Heterobranchus longiflis, Clarias gariepinus and Clarias anguillaris in sodium dodecyl sulphate polyacrylamide gel electrophoresis (SDS-PAGE). Int J Fish Aquac 2012; 4(10): 202-8.

37. Gicking JC, Foley AM, Harr KE, Raskin RE, Jacobson E. Plasma protein electrophoresis of the Atlantic Loggerhead sea turtle, Caretta caretta. J Herpetol Med Surg 2004; 14(3): 13-8. 